\title{
Marriage in Cinema
}

\author{
Priju Varghese ${ }^{\mathrm{a}}$
}

Marriage is a topic that has been dealt by Hollywood since the beginning of motion pictures. Even though the subject of marriage seems to be banal, there is a wide diversity in how people lead their married lives. Factors such as culture, religion, education, and history have had major influences on the perception and definition of marriage. Hollywood, which has always been deft to notice the evolution in marriage, has portrayed them through the use of movies. Through this paper, the researcher intends to chart the development in the concept of marriage through cinema over the past century.

Keywords: Marriage; cinema; analysis

The concept of marriage is probably as old as the beginning of human life on Earth. Human beings always have the need for companionship and love. Since, men have the sperm and women have the eggs and uterus for carrying and giving birth, the union of men and women made perfect sense. As time went by, especially since the establishment of various religions, marriage became a sanctified ritual. Various religions proclaimed that marriage was essential for procreation and continuation of the human lineage. Now, in the twenty first century, the concept of marriage has gained new dimensions. Marriage is not only the union between a man and a woman anymore. The union between people from the same gender is increasingly being allowed and recognized as marriage. The writer of this paper is not concerned about the ongoing national debate about the true definition of marriage. To be fair, marriage is not necessary for the process of procreation. But, a stable family is important for the proper mental and physical well-being of children. Then again, a family headed by a man and a woman does not guarantee a peaceful household. All of the aforementioned questions and themes have been developed and presented by Hollywood over the past century. The movies from various periods over the last hundred years reflect the societal perceptions about marriage. Besides studying the evolution in marriage, an attempt has been made by the author of this paper to note the changes in the dynamics between the two partners in marriage.

During the first half of the twentieth century, marriage between a man and woman continued along traditional lines. Men were the primary bread winners of their families while most women were house wives. Another common feature of these marriages was the ages of the couples. Most of the couples married in their early twenties; some right after high school. Because the writer of this paper is twenty-three years old himself, a marriage at such early years is a huge life changing event for people just entering into maturity. Therefore, most of these young couples faced enormous difficulties in handling the challenges of marriage.

A prominent Hollywood movie that deals with the difficulties of early marriages is a 1967 movie directed by Gene Saks called Barefoot In the Park. The movie depicts the struggles of a young newlywed couple; Paul Bratter (Robert Redford) and Corrie (Jane Fonda). Paul Bratter is a conventional and uptight lawyer as opposed to the vivacious and free spirited Corrie. After their blissful and romantic one week honeymoon, problems begin to surface between them.
Paul and Corrie start to realize the difficulties in adjusting to their opposing personalities. Besides their interpersonal conflicts, the couple also carries baggage from their childhood. Since they are relatively young, they moved on to the marriage phase without actually resolving any of their childhood conflicts. Paul develops a fondness for Corrie's mother since his own mother passed away when he was young. This creates jealousy in Corrie and she resolves to find a partner for her widowed mother who happens to be her upstairs neighbor; Mr. Velasco (Charles Boyer). In the meantime, Corrie develops a father like attraction towards Mr. Velasco since her own father passed away when she was young. The climax of the movie is a resolution of all the aforementioned conflicts. Corrie finds a drunk and barefoot Paul dancing in the park. When she sees such a behavior from the usually uptight Paul, Corrie (the free spirited person) scolds him. In this final scene, the couple who were initially dumfounded by their completely opposite natures has started to absorb elements from each other's personalities. "Ideally, the partners retain main and major aspects of their private selves while renouncing some autonomy and also gradually taking in the internal objects of the partner." (Akthar and Billinkoff, 2011) Even though Hollywood specializes in happy endings, young couples would need to have good guidance in order to work through those aforementioned conflicts.

The 1970s ushered in the feminist movement. The movement spearheaded by activists such as Gloria Steinem redefined the traditional gender roles. Until then, men were the bread winners responsible for bringing in the money. On the other hand, women had to stay at home and take care of the domestic duties. However, a lot of women were not happy to confine their lives within the four walls of their homes. They started to demand equal share of everything that men used to solely command in the society.

As always, Hollywood began to cash in on the dramatic changes that were happening in the country. One of the movies that reflected the changing perceptions in the gender roles is a 1979 movie called Kramer vs. Kramer. This movie is the story about the troubled marital relationship and divorce of Ted Kramer (Dustin Hoffman) and Joana Kramer (Meryl Streep). Ted is a busy business executive while Joana is a housewife. The movie begins with Joana packing her bags and kissing her son goodbye in order to leave the house. Even though Ted tries to stop her, Joana leaves. Based on the confrontational dialogue between Ted and Joana, it is clear to 
the audience that Joana was tired of leading her life as a home maker. She is an educated woman with a career that she had to leave after marriage because Ted felt that it did not yield enough money. The years of frustration due to her unfulfilled dreams causes her to leave the family. The remaining portions of the movie depict Ted's struggles to take care of his five year old child, Billy. As soon as Ted adjusts to his life as a businessman and father, Joana arrives to claim custody of their child. She informs him of her new career with a salary that is higher than Ted's pay. Then, the film shifts to the famous courtroom custody battle scene. The movie ends on a "happy and sad" note when Joana informs Ted about her decision to give up her claim for Billy's custody and they embrace each other. The reason why the movie is revered by feminists is because the female character shows the courage to leave her husband and child for her own development. However, the writer of this article does not believe that the notion of self-fulfillment necessarily comes with independence. As researcher Toni Mandelbaum suggests, "Relationship dissolution in the name of personal freedom may in the end, bring personal anxiety and a life void of attachment. Perhaps engaging in an emotionally intimate relationship actually propels one forward into personal happiness." (2011)

The Vietnam War and its failure during the 1970s plunged the American masculinity into a crisis situation. Again, Hollywood took note of the situation and came to the rescue by releasing movies that effectively uplifted the morale of the male gender. A series of movies were produced and released during the 1980s that starred gun wielding macho muscular stars such as Sylvester Stallone, Arnold Schwarzenegger and Jean Claude Van Damme. These movies were focused on the testosterone fueled actions and mass killings with wide bloodshed. Hence, family life and marital relationships did not hold any thematic relevance in these movies. As a matter of fact, there weren't any female actors in such movies. Even if there were female heroines, they were either part of the killing crusade or were an insignificant, one scene character such as the mother or wife of the leading man. Researcher Constantin Parvulescu perfectly sums up the role of the female characters in these movies, "She is the true subaltern of this world-without a name, without a voice, without a story." (2009) Often, the role of the heroines were replaced by male stars or "buddies." For example, the Rambo Franchise is the story of revenge implemented by Vietnam War veteran, John Rambo, against his enemies. This typical gory film of the 1980's has no female stars, but, instead, Richard Crenna, as Colonel Sam Trautman, plays Rambo's ally and confidante. The Colonel effectively replaces the female character and the movie focuses on the relationship between the two main male characters. The production of such films did not begin in the 1980's because films like Butch Cassidy and the Sundance Kid (1969) and Midnight Cowboy (1969) ran along similar storylines. However, there was a dramatic increase in the number of buddy films during the 1980's and 1990's.

The 1990s came with a new genre of movies known as the "office movies." As the name itself suggests, the main leading character of this type of movies is a middle class office worker who spends a major portion of his day in a cubicle. At the end of an eight hour day, he comes home tired, eats dinner and goes to sleep. Such a monotonous routine takes him away from his family. After decades of living his life inside a 6" X 6" office cubicle, the leading man becomes frustrated, bored and disillusioned. He is distraught about not being able to spend time with his wife and children. One of the prominent movies that describe the aforementioned theme is a 1999 film called American Beauty. The plot of the movie concern a middle-aged man named Lester Burnham (Kevin Spacey) who is working as a magazine writer. He absolutely despises his job. Lester has a frustrating family life because his wife Carolyn (Annette Bening) is a domineering person. They frequently fight with each other. However, as researcher Matthew Alexander states in his article; "the difference between successful and unsuccessful couples is not about whether they fight or not but how they fight." (2009) Carolyn also begins to have an affair with her boss. They have a daughter, Jane, who is neglected by both of them and she begins a relationship with her neighbor. The main twist of the plot arrives when Lester starts to develop a liking towards his daughter's beautiful friend; Angela Hayes. After becoming motivated to earn her love, Lester starts to dramatically change his life. He quits his boring job, becomes a fast food employee, buys his dream car, joins a gym and smokes marijuana. This shift in Lester's lifestyle ends in tragedy. In the climax of the movie, Lester is shot killed by Jane's boyfriend's father. However, he has an epiphany right after trying to have sex with Angela. Lester realizes that it was foolish for him to lust after his daughter's friend and that his family should have been his main priority.

The new millennium brought dramatic changes in Hollywood. Hollywood started to embrace bold and controversial themes through their films. One of the topics that movies began to analyze in depth was homosexuality. Even though there had been movies in the past that dealt with homosexuality such as Cat on a Hot Tin Roof (1959) and Dog Day Afternoon (1975), homosexuality were either portrayed in an unflattering light or not discussed in depth. However, numerous movies were produced and released in the 2000's that portrayed the various issues of the LGBT community such as coming out, romance, relationships, marriage and family. The Kids Are All Right (2010) is one such movie that discusses the family dynamics of a lesbian household. Nicole Allgood (Annette Bening) and Jules Allgood (Julianne Moore) are a married couple. They have two children born through artificial insemination; Joni and Laser. Nicole is an OB/GYN while Jules is a stay-at-home mom. However, Jules desires to start up a landscape company which Nicole does not support. When the kids realize that they both have the same biological father, they decide to find and meet him (Paul). Nicole and Jules find out about their kids' meeting with Paul and they decide to invite him over for dinner. The kids like Paul and start to spend time with him which doesn't please Nicole. One day, Jules leaves their home and visits Paul after an intense argument with Nicole. Paul and Jules share a kiss and spend the night together. Jules' infidelity creates serious friction in their marital relationship. However, at the end, Jules apologizes to the family for her mistake and they all once again become a loving and caring family.

The Kids Are All Right is an important film due to several reasons. First of all, the issues portrayed in the movie such as infidelity, marital conflicts and problems with children are exactly the same as heterosexual households. The children grow up in a regular and loving family with guidance 
from two female parental figures. The only "unconventional" thing in the Allgood household may be the two women; Nicole and Jules, but, if such a family could become a functional unit of our society, then is it morally wrong? Both women are highly educated and valuable members of their community. Therefore, these women would never jump into the decision of forming a family without carefully thinking about the consequences and the societal perceptions. This movie has definitely played an important role in alleviating the stereotypical perceptions about the LGBT households.

One thing that is clearly evident from the aforementioned research is that marriage has never had a clear cut definition. The process of marriage began as a cultural construction by human beings to satisfy their need for companionship and love. Slowly, religion took marriage and made it into a ritual with codes and regulations. The sanctified ritual of marriage was enforced by the Church and State for thousands of years. However, human beings, known for their inquisitive nature, started to question the "set definitions" of marriage. With the freedom guaranteed by the constitution, certain people chose to set up families that defy the tradition. Hollywood has always taken special care to capture these changes with the help of a camera and bring it to the masses using the medium of cinema.

\section{References}

Akhtar, S., Billinkoff, Z. (2011). Developmental Tasks Of Early Marriage: Barefoot in the Park (1967), Raising Arizona (1987), The Quiet Man (1952). Retrieved from www.palgrave-journals.com/ajp/.

Alexander, M. (2009). The Couple's Odyssey: Hollywood's Take on Love Relationships. Retrieved from http://www.ncbi.nlm.nih.gov/pubmed/19459092

Mandelbaum, T. (2009). Psychological Tasks Associated With Divorce: Eat, Pray, Love (2011), An Unmarried Woman (1978) And Kramer vs. Kramer (1979). Retrieved from from www.palgrave-journals.com/ajp/.

Parvulescu, C. (2009). Betrayed Promises: Politics and Sexual Revolution in the Films of Mảrta Mẻszảros, Milos Forman, and Dusan Makavejev. Retrieved from http://cameraobscura.dukejournals.org/content/24/2_71/77. abstract 